\title{
ELECTROPHORETIC ANALYSIS OF THE PROTEINS OF PLASMA AND SEROUS EFFUSIONS
}

\author{
By JOHN A. LUETSCHER, JR. \\ (From the Departments of Physical Chemistry and Medicine, Harvard Medical School, \\ and from the Medical Clinic of the Peter Bent Brigham Hospital, Boston)
}

(Received for publication August 12, 1940)

The basic characteristics of serous effusions are well established. The matrix of water and salt is nearly identical with that of blood $(1,2)$. The cells, derived from blood or from tissues in contact with the effusion, vary widely in type and number. The protein content also varies within wide limits, and the specific gravity of the fluid with it $(3,4,5)$.

Serous effusions are classically divided into "transudates" and " exudates," implying different mechanisms of formation. The transudate is supposed to be produced by mechanical factors, such as change in hydrostatic or colloid osmotic pressure, while the exudate is produced by the reaction of the serous membrane to the presence of bacteria or noxious substances. Practically, the differentiation is made on the specific gravity, the cell count, and the presence or absence of clotting. This division is very useful, but shows some defects on closer examination. Not infrequently the distinction is difficult to make with the fluid in hand, as the white cell count and the specific gravity are not clearly in one class or another, the dividing line being ill-defined. Also, there is no place in the classification for fluids of neoplastic origin.

In an attempt to evaluate the factors involved in the production of serous effusions and to determine the presence or absence of a sharp distinction between the various types of fluid, the proteins of the fluids have been studied by electrophoresis and compared with the proteins of the blood in each case.

Blood proteins vary both in size and in net charge. Rate of migration in an electric field depends on both of these factors and allows the differentiation into more fractions than can be clearly detected by fractional precipitation by neutral salts or by ultracentrifugal analysis. This method also has the advantage of an accuracy greater than that of the so-called salting-out methods (11) and permits the quantitative estimation of albumin, fibrinogen and the three chief globulin fractions.

\section{METHODS}

The electrophoresis apparatus of Tiselius was used (6). Plasma is layered in the lower half of the $U$-tube under buffer, against which the plasma has previously been dialyzed. Direct current is applied, and under its influence the original plasma-buffer boundary breaks up into a number of boundaries moving at different speeds, representing protein fractions of different electrophoretic mobilities under the conditions of $\mathrm{pH}$ and ionic strength used.

At each of these "boundaries" there is a change in protein concentration and a corresponding change in refractive index. The change in refractive index is measured by the downward deflection of a beam of light passing through the boundary and recorded for each position along the $U$-tube by the automatic camera developed by Philpot (23) and Svensson (9). The resultant diagram consists of a number of peaks, each corresponding to a boundary. The area under each peak is proportional under constant conditions to the concentration of the protein fraction which the boundary represents.

The pattern obtained by the electrophoresis of plasma varies with the $\mathrm{pH}$ and to some extent with the ionic strength. Buffering was accomplished by phosphate at pH 7.7. An ionic strength of 0.20 was found useful in separating the slowest globulin fraction from the socalled $\delta$-effect, which appears at the site of the original protein-buffer boundary. Plasma and fluid were diluted with two parts of buffer and dialyzed against a large volume of buffer for twenty-four hours with stirring, in order to allow salt concentrations to reach Donnan equilibrium and to minimize differences in conductivity and $\mathrm{pH}$.

\section{RESULTS}

1. Normal blood. The order of migration of the chief protein fractions of human plasma in buffers at $\mathrm{pH} 7.7$ is albumin, $\alpha$-globulin, $\beta$ globulin, fibrinogen and $\gamma$-globulin. These boundaries were first noted in horse serum by Tiselius (7), later in human plasma by Stenhagen (8).

Concerning the proportions of these fractions in human plasma and serum, there is excellent 
agreement of results from different laboratories $(9,10,11)$. The normal variation in proportions is apparently slight, although total protein concentration is somewhat more variable. Average values for normal plasma are given in Table I, 1 .

It is an obvious simplification to divide the blood proteins into these five major electrophoretic fractions. There are many important proteins which find no place in the electrophoretic analysis of whole plasma because they are present in amounts too small to be detected. Among these are the enzymes (e.g., acetylcholine esterase and phosphatase) and haemocuprein. In addition to these substances, the five fractions are themselves complex. In a previous report, we demonstrated that

TABLE I

Percentage composition of proteins of plasma and effusions

\begin{tabular}{|c|c|c|c|c|c|c|}
\hline & $\begin{array}{c}\text { Total } \\
\text { protein }\end{array}$ & $\underset{\text { min }}{\text { Albu- }}$ & $\alpha$ & $\boldsymbol{\beta}$ & $\boldsymbol{\gamma}$ & $\begin{array}{c}\text { Fibrin } \\
\text { ogen }\end{array}$ \\
\hline \multicolumn{7}{|c|}{ NORMAL PLASMA (1) } \\
\hline Plasma. & 6.5 & 62.5 & 7.0 & 13.2 & 11.6 & 5.7 \\
\hline \multicolumn{7}{|c|}{ CIRRHOSIS (2) } \\
\hline $\begin{array}{l}\text { Plasma. } \\
\text { Ascites. }\end{array}$ & $\begin{array}{l}5.7 \\
0.6\end{array}$ & $\begin{array}{l}39.3 \\
41.1\end{array}$ & $\begin{array}{l}5.8 \\
4.5\end{array}$ & $\begin{array}{l}14.2 \\
13.8\end{array}$ & $\begin{array}{l}32.0 \\
34.5\end{array}$ & $\begin{array}{l}8.7 \\
6.1\end{array}$ \\
\hline $\begin{array}{l}\text { Plasma. } \\
\text { Ascites. }\end{array}$ & $\begin{array}{l}5.3 \\
0.5\end{array}$ & $\begin{array}{l}38.3 \\
52.0\end{array}$ & $\begin{array}{l}5.0 \\
3.4\end{array}$ & $\begin{array}{l}26.2 \\
20.0\end{array}$ & $\begin{array}{l}24.4 \\
22.5\end{array}$ & $\begin{array}{l}6.1 \\
2.1\end{array}$ \\
\hline $\begin{array}{l}\text { Plasma.. } \\
\text { Ascites. . }\end{array}$ & $\begin{array}{l}5.3 \\
0.3\end{array}$ & $\begin{array}{l}35.8 \\
48.0\end{array}$ & $\begin{array}{l}7.0 \\
6.5\end{array}$ & $\begin{array}{l}26.4 \\
19.5\end{array}$ & $\begin{array}{l}27.3 \\
26.0\end{array}$ & $\underline{3.6}$ \\
\hline \multicolumn{7}{|c|}{ CARDIAC FAILURE (3) } \\
\hline $\begin{array}{l}\text { Plasma.......... } \\
\text { Pericardial.... }\end{array}$ & $\begin{array}{l}7.0 \\
3.7\end{array}$ & $\begin{array}{l}45.1 \\
63.8\end{array}$ & $\begin{array}{l}5.9 \\
5.6\end{array}$ & $\begin{array}{l}21.0 \\
10.1\end{array}$ & $\begin{array}{l}22.8 \\
16.8\end{array}$ & $\begin{array}{l}5.2 \\
3.7\end{array}$ \\
\hline $\begin{array}{l}\text { Plasma.... } \\
\text { Pleural. ... } \\
\text { Pleural 2.. }\end{array}$ & $\begin{array}{l}5.7 \\
1.8 \\
2.0\end{array}$ & $\begin{array}{l}45.0 \\
58.6 \\
61.6\end{array}$ & $\begin{array}{l}8.0 \\
7.8 \\
6.0\end{array}$ & $\begin{array}{l}22.0 \\
14.3 \\
10.5\end{array}$ & $\begin{array}{l}20.0 \\
15.7 \\
17.9\end{array}$ & $\begin{array}{l}5.0 \\
3.6 \\
4.0\end{array}$ \\
\hline $\begin{array}{l}\text { Plasma. } \\
\text { Pleural. }\end{array}$ & $\begin{array}{l}6.8 \\
2.0\end{array}$ & $\begin{array}{l}44.8 \\
57.3\end{array}$ & $\begin{array}{l}3.6 \\
9.3\end{array}$ & $\begin{array}{l}29.1 \\
13.7\end{array}$ & $\begin{array}{l}15.2 \\
14.9\end{array}$ & $\begin{array}{l}7.3 \\
4.8\end{array}$ \\
\hline $\begin{array}{l}\text { Plasma... } \\
\text { Pleural... } \\
\text { Pleural } 2 .\end{array}$ & $\begin{array}{l}5.7 \\
2.0 \\
2.2\end{array}$ & $\begin{array}{l}48.7 \\
61.1 \\
57.5\end{array}$ & $\begin{array}{l}4.6 \\
4.3 \\
5.1\end{array}$ & $\begin{array}{l}27.1 \\
12.2 \\
14.7\end{array}$ & $\begin{array}{l}15.1 \\
18.1 \\
17.6\end{array}$ & $\begin{array}{l}4.5 \\
4.3 \\
5.1\end{array}$ \\
\hline $\begin{array}{l}\text { Plasma. } \\
\text { Pleural. } \\
\text { Ascites. }\end{array}$ & $\begin{array}{l}5.3 \\
1.1 \\
1.1\end{array}$ & $\begin{array}{l}32.7 \\
37.0 \\
41.1\end{array}$ & $\begin{array}{l}6.1 \\
4.4 \\
4.2\end{array}$ & $\begin{array}{l}39.1 \\
32.9 \\
30.5\end{array}$ & $\begin{array}{l}18.4 \\
15.4 \\
16.8\end{array}$ & $\begin{array}{r}3.7 \\
10.3 \\
7.4\end{array}$ \\
\hline $\begin{array}{l}\text { Plasma.. } \\
\text { Pleural. . }\end{array}$ & $\begin{array}{l}4.7 \\
1.0\end{array}$ & $\begin{array}{l}42.2 \\
50.0\end{array}$ & $\begin{array}{l}13.1 \\
13.1\end{array}$ & $\begin{array}{l}24.3 \\
18.1\end{array}$ & $\begin{array}{l}14.9 \\
14.5\end{array}$ & $\begin{array}{l}5.6 \\
4.3\end{array}$ \\
\hline $\begin{array}{l}\text { Plasma... } \\
\text { Pleural. . }\end{array}$ & $\begin{array}{l}6.3 \\
1.0\end{array}$ & $\begin{array}{l}57.2 \\
66.6\end{array}$ & $\begin{array}{l}4.2 \\
5.3\end{array}$ & $\begin{array}{r}16.0 \\
9.4\end{array}$ & $\begin{array}{l}17.2 \\
12.5\end{array}$ & $\begin{array}{l}5.4 \\
6.2\end{array}$ \\
\hline
\end{tabular}

TABLE I (Continued)

\begin{tabular}{|c|c|c|c|c|c|c|}
\hline & $\begin{array}{c}\text { Total } \\
\text { protein }\end{array}$ & $\underset{\text { min }}{\text { Albu- }}$ & $\boldsymbol{\alpha}$ & $\boldsymbol{\beta}$ & $\boldsymbol{\gamma}$ & $\begin{array}{l}\text { Fibrin- } \\
\text { ogen }\end{array}$ \\
\hline \multicolumn{7}{|c|}{$\begin{array}{l}\text { TERMINAL GLOMERULONEPHRITIS (4) } \\
\text { WITH HEART FAILURE }\end{array}$} \\
\hline $\begin{array}{l}\text { Plasma....... } \\
\text { Pleural, right ... } \\
\text { Pleural, left... }\end{array}$ & $\begin{array}{l}6.0 \\
0.95 \\
0.9\end{array}$ & $\begin{array}{l}43.1 \\
67.0 \\
65.6\end{array}$ & $\begin{array}{l}3.1 \\
4.5 \\
4.7\end{array}$ & $\begin{array}{l}31.2 \\
12.0 \\
12.5\end{array}$ & $\begin{array}{l}16.3 \\
12.0 \\
12.5\end{array}$ & $\begin{array}{l}6.3 \\
4.5 \\
4.7\end{array}$ \\
\hline \multicolumn{7}{|c|}{ LOBAR PNEUMONIA (5) } \\
\hline $\begin{array}{l}\text { Plasma... } \\
\text { Pleural. . }\end{array}$ & $\begin{array}{l}5.6 \\
4.0\end{array}$ & $\begin{array}{l}40.6 \\
50.5\end{array}$ & $\begin{array}{l}10.3 \\
14.5\end{array}$ & $\begin{array}{l}26.8 \\
19.1\end{array}$ & $\begin{array}{l}13.6 \\
13.8\end{array}$ & $\begin{array}{l}8.7 \\
2.1\end{array}$ \\
\hline $\begin{array}{l}\text { Plasma.... } \\
\text { Pleural... }\end{array}$ & $\begin{array}{l}5.3 \\
3.4\end{array}$ & $\begin{array}{l}33.5 \\
49.2\end{array}$ & $\begin{array}{l}17.0 \\
14.0\end{array}$ & $\begin{array}{l}24.8 \\
12.2\end{array}$ & $\begin{array}{l}17.0 \\
17.1\end{array}$ & $\begin{array}{l}7.7 \\
7.5\end{array}$ \\
\hline Pericardial..... & 3.3 & 58.3 & 12.8 & 16.5 & 12.4 & \\
\hline
\end{tabular}

TUBERCULOSIS (6)

\begin{tabular}{l|r|r|r|r|r|r}
\hline Plasma........ & 6.3 & 52.2 & 9.9 & 17.6 & 13.1 & 7.2 \\
Pleural........ & 4.4 & 61.6 & 7.0 & 13.7 & 14.0 & 3.7 \\
& & & & & \\
Plasma........ & 5.7 & 36.1 & 9.5 & 10.9 & 32.1 & 11.4 \\
Ascites........ & 2.4 & 37.5 & 7.7 & 8.5 & 39.3 & 7.0 \\
\hline
\end{tabular}

CARCINOMA (7)

\begin{tabular}{|c|c|c|c|c|c|c|}
\hline $\begin{array}{l}\text { Plasma. . } \\
\text { Ascites. . }\end{array}$ & $\begin{array}{l}5.8 \\
3.5\end{array}$ & $\begin{array}{l}39.4 \\
49.3\end{array}$ & $\begin{array}{r}14.9 \\
8.7\end{array}$ & $\begin{array}{l}21.0 \\
15.3\end{array}$ & $\begin{array}{l}16.7 \\
20.5\end{array}$ & $\begin{array}{l}8.0 \\
6.2\end{array}$ \\
\hline $\begin{array}{l}\text { Plasma......... } \\
\text { Ascites....... }\end{array}$ & $\begin{array}{l}6.7 \\
3.5\end{array}$ & $\begin{array}{l}57.9 \\
76.3\end{array}$ & $\begin{array}{r}10.2 \\
6.6\end{array}$ & $\begin{array}{r}20.8 \\
9.1\end{array}$ & $\begin{array}{l}6.9 \\
7.0\end{array}$ & $\begin{array}{l}4.2 \\
1.0\end{array}$ \\
\hline $\begin{array}{l}\text { Plasma... } \\
\text { Ascites... }\end{array}$ & $\begin{array}{l}6.0 \\
1.2\end{array}$ & $\begin{array}{l}52.1 \\
57.3\end{array}$ & $\begin{array}{l}6.5 \\
5.9\end{array}$ & $\begin{array}{l}16.0 \\
13.9\end{array}$ & $\begin{array}{l}16.3 \\
15.3\end{array}$ & $\begin{array}{l}9.1 \\
7.6\end{array}$ \\
\hline \multicolumn{7}{|c|}{ HODGKIN'S DISEASE (8) } \\
\hline $\begin{array}{l}\text { Plasma. } \\
\text { Pleural. }\end{array}$ & $\begin{array}{l}6.2 \\
3.5\end{array}$ & $\begin{array}{l}47.5 \\
53.9\end{array}$ & $\begin{array}{l}14.5 \\
13.5\end{array}$ & $\begin{array}{l}16.8 \\
12.7\end{array}$ & $\begin{array}{l}15.5 \\
15.4\end{array}$ & $\begin{array}{l}5.7 \\
4.5\end{array}$ \\
\hline
\end{tabular}

the albumin fraction separated into two components at $\mathrm{pH} 4.0$ (12). The $\beta$ - and $\gamma$-globulin fractions each showed at least two components when certain plasmas were studied at $\mathrm{pH}$ 7.7. The division into five fractions must therefore be regarded as only the first approximation in the quantitative analysis of the proteins of plasma.

The composition of the electrophoretic fractions has been discussed in some detail in a previous communication (11).

2. Nephrotic syndrome. There is no difference in the protein analysis between those cases with or without the history or present evidence of glomerulonephritis.

The plasma proteins show a severe loss of al- 

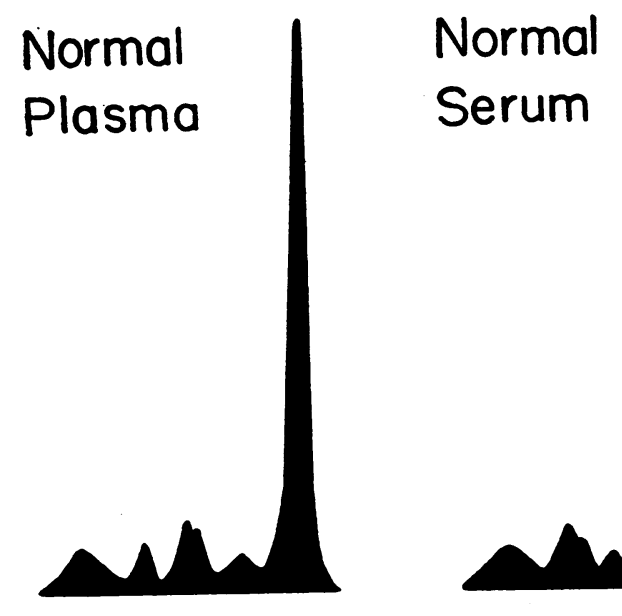

\section{Cirrhosis}

\section{Plasma}

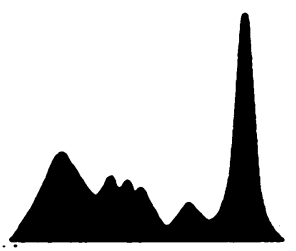

\section{Ascites}

Fig. 1. Schlieren Diagrams of Normal Plasma and Serum and of the Plasma and Ascitic Fluid in Portal Cirrhosis

The area under each peak represents the concentration of that fraction of the plasma proteins. From left to right (slowest to fastest migration rates) plasma shows $\gamma$-globulin, fibrinogen, the double $\beta$-globulin peak, aglobulin, and albumin. In serum, fibrinogen naturally does not appear.

bumin, with increase first of $\beta$-globulin and fibrinogen. The $\alpha$-globulin rises as the albumin reaches very low levels, while $\gamma$-globulin is uniformly decreased.

The pleural and ascitic fluids from these cases are very low in protein content ( 0.1 to 0.7 gram per cent) and quite milky in appearance. These two properties make the fluids very difficult to analyze accurately by electrophoresis. It can only be said that the pattern of the fluid roughly resembles that of the plasma, but with a somewhat higher proportion of albumin.

The urinary protein, however, is very high in albumin (11). When the blood albumin represents one quarter of the blood protein, the urinary albumin may constitute nine-tenths of the protein lost. Similarly, as Longsworth and MacInnes (13) pointed out, the urinary protein may resemble the distribution in normal serum when the blood albumin is almost totally gone.

The albumins of blood and urine in the nephrotic syndrome show a ratio of components opposite to the normal ratio when the albumins are studied by electrophoresis at $\mathrm{pH} 4.0$ (12). There is no significant difference between nephrotic blood and urinary albumin in this respect, apparently indicating some difference in the mechanism of albumin formation.

3. Portal cirrhosis. In this disease, the presence or absence of ascites can generally be correlated with the changes in the blood proteins. In the early stages, the total protein is normal or occasionally elevated. The albumin, however, is both relatively and absolutely diminished. The $\beta$ - and $\gamma$-globulins are increased. Later, the total protein falls to a level usually about 5.5 grams per cent, with the albumin below 2.5 grams per cent, and ascites appears $(24,25,26)$. At this stage, the ratio of albumin components at $\mathrm{pH} 4.0$ is reversed. The $\gamma$-globulin is most strikingly increased. Fibrinogen is usually normal (Table I, 3).

The ascitic fluid in cirrhosis contains little protein, varying from 0.3 to 0.6 per cent in our cases. The distribution of protein fractions reflects that of plasma, but with relatively more albumin present. In the first few taps, the proportion of albumin is considerably higher in the ascitic fluid than in the plasma. Later, with multiple taps, the ascitic fluid may approach the protein distribution of plasma.

4. Congestive heart failure. Our results confirm the conclusion of Payne and Peters (14) that the concentration of that plasma albumin is lowered in cardiac failure. We find, however, that the globulin concentration is somewhat increased, and that this is due to an absolute increase of $\beta$ - and $\gamma$-globulin (Table I, 4). The $\alpha$-globulin and fibrinogen concentrations are normal or slightly reduced unless considerable fever is present, with the usual increase of $\alpha$-globulin. In general, the albumin decrease is reflected in a low total plasma protein, and the lowest total proteins occur in plasma where albumin is most diminished. Globulin increase is present in all of our cases, 
Cardiac Failure Plasma

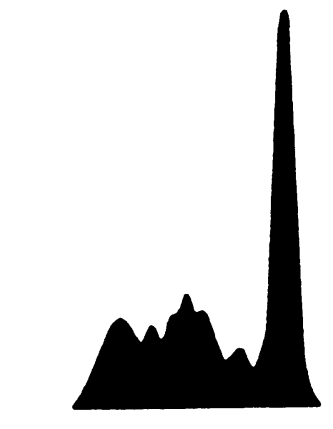

\section{Pneumonia}

Plasma

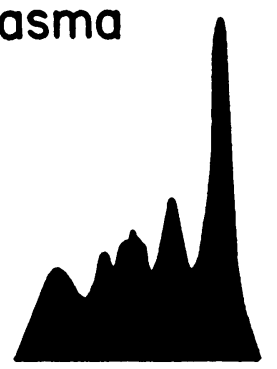

Pleural Fluid

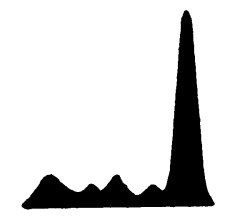

\section{Pleural Fluid}

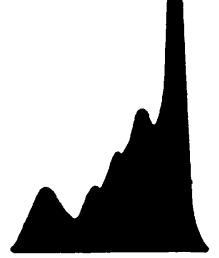

Fig. 2. Schlieren Diagrams of Plasma and Pleural Fluids in Cardiac Failure and Lobar Pneumonia

but does not bear any fixed relationship to the concentration of albumin.

The pleural, pericardial, and ascitic fluids from a single case of cardiac failure show small differences in total protein and no significant difference in composition, so long as no localized inflammation or bleeding affects the fluid in one cavity. The fluids differ from the patient's plasma in protein distribution in that albumin is proportionately higher and $\beta$-globulin lower (Figure 2). The total protein concentration of the fluids varied from 1.0 to 3.7 grams per $100 \mathrm{cc}$.

The ratio of the proportion of albumin in the fluid to the proportion of albumin in the plasma increases as the protein content of the fluid increases (Figure 5). Effusions with low protein content thus resemble diluted plasma, while fluids with high protein content contain proportionately more albumin.

If inflammation or bleeding occurs in a serous cavity during cardiac failure, the fluid naturally shows an increase in protein, the distribution of

which will generally be more characteristic of the intercurrent event.

In one patient with terminal glomerulonephritis, hypertension and cardiac failure, the pleural fluid contained somewhat less protein and a higher proportion of albumin than one would expect if the basis were simple cardiac failure. The protein distribution of the pleural fluid is much like that of the urine, except that the urine contains no evidence of fibrinogen or of one of the $\beta$-globulin peaks, due perhaps to the insolubility of these fractions in dilute acid solutions.

5. Lobar pneumonia. In cases of lobar pneumonia with pleural effusion, the distribution of plasma proteins is considerably modified (Figure 2). As Blix (15) pointed out, the $\alpha$-globulin is consistently increased. In our cases with effusion, the average concentration of $\alpha$-globulin is twice the normal value, albumin is decreased to about

\section{Tuberculosis \\ Plasma}

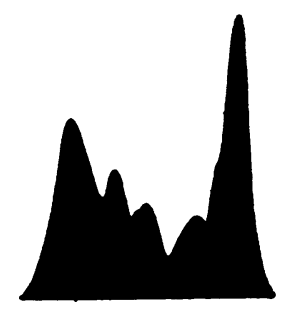

Carcinoma

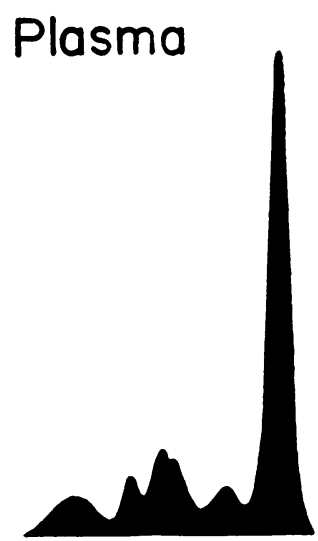

\section{Ascites}
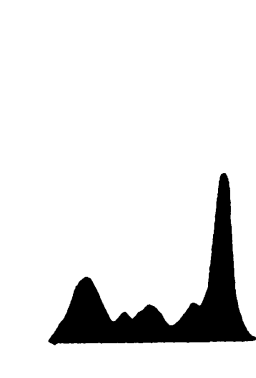

Ascites
Fig. 3. Schlieren Diagrams of Plasma and Ascitic Fluids in Tuberculosis and Carcinomatosis of the Peritoneal Cavity 
one-half of its normal concentration, $\beta$ - and $\gamma$ globulins are usually increased, and fibrinogen is consistently high (Table I, 5).

In the effusions, the protein content was high, 3.3 to 4.0 grams per cent. The albumin concentration was very close to that of the blood; the globulin concentration somewhat lower. The fibrinogen content of the fluid was usually still lower, apparently due to some defibrination by the pleura. In no case was there any evidence of selective secretion of any one protein fraction into the fluid. The single pericardial fluid studied does not differ from those from the pleura.

6. Tuberculosis. In common with other febrile diseases, the plasma in active tuberculosis shows an increase in $\alpha$-globulin (Figure 3). Albumin is also reduced to a variable extent, and fibrinogen elevated. Increased $\boldsymbol{\gamma}$-globulin may occur in chronic active cases (Table $I, 6$ ).

Tuberculous effusions are relatively high in protein content and reflect the changes in the blood. In cases with severe malnutrition, the blood protein may be reduced sufficiently to make the fluid more dilute than is usually seen in an inflammatory fluid.

7. Neoplastic disease. As might be expected, the fluids occurring in connection with tumors are extremely variable, depending on the means by which the fluid is produced. There may be hemorrhage or oozing of serum into a serous cavity from invasion of the lining. In this case, the blood may be normal and the fluid is nearly identical with blood in terms of protein content. In other cases, the situation of the tumor may give rise to localized obstruction of veins and lymphatics, leading to a more dilute fluid resembling that of cardiac failure. Malnutrition with or without the loss of protein-containing fluid may lead to severe hypoproteinemia. "Mucinous" fluids usually contain much more plasma protein than mucin. Each situation must be evaluated on the facts of the individual case.

\section{DISCUSSION}

Serous effusions appear to contain the same major protein fractions as blood plasma (Table II), and the relative composition is somewhat similar. Albumin is usually present in higher proportion in the serous fluid than in the blood
TABLE II

Relative mobilities of plasma and effusion proteins in phosphate buffer of pH 7.7 and ionic stremgth 0.20

(Estimated from descending boundary)

\begin{tabular}{|c|c|c|c|c|c|}
\hline \multirow{3}{*}{ Source } & \multicolumn{5}{|c|}{ Mobility $\times 100$} \\
\hline & \multirow{2}{*}{$\underset{\min }{\text { Albu- }}$} & \multicolumn{3}{|c|}{ Globulins } & \multirow{2}{*}{$\underset{\text { Ogen }}{\text { Fibrin- }}$} \\
\hline & & a & $\boldsymbol{\beta}$ & $\boldsymbol{r}$ & \\
\hline Normal Plasma.... & 5.1 & 3.8 & 2.7 & 0.9 & 1.9 \\
\hline $\begin{array}{r}\text { Cirrhosis Plasma } \ldots \ldots \\
\text { Ascites . . . . . . . }\end{array}$ & $\begin{array}{l}5.2 \\
4.9\end{array}$ & $\begin{array}{l}4.0 \\
3.9\end{array}$ & $\begin{array}{l}2.8 \\
2.7\end{array}$ & $\begin{array}{l}0.9 \\
0.9\end{array}$ & $\begin{array}{l}2.0 \\
1.9\end{array}$ \\
\hline $\begin{array}{r}\text { Cirrhosis Plasma . . } \\
\text { Ascites ..... . }\end{array}$ & $\begin{array}{l}5.1 \\
5.0\end{array}$ & $\begin{array}{l}3.8 \\
3.8\end{array}$ & $\begin{array}{l}2.7 \\
2.7\end{array}$ & $\begin{array}{l}0.9 \\
0.9\end{array}$ & $\begin{array}{l}2.0 \\
1.9\end{array}$ \\
\hline $\begin{array}{r}\text { Cardiac Plasma } \ldots \ldots \\
\text { Pleural fluid } \ldots \ldots \\
\text { Ascites } \ldots \ldots \ldots\end{array}$ & $\begin{array}{l}5.1 \\
5.1 \\
5.0\end{array}$ & $\begin{array}{l}3.8 \\
3.8 \\
3.7\end{array}$ & $\begin{array}{l}2.9 \\
2.7 \\
2.6\end{array}$ & $\begin{array}{l}0.9 \\
0.9 \\
0.9\end{array}$ & $\begin{array}{l}2.0 \\
2.0 \\
1.9\end{array}$ \\
\hline $\begin{array}{r}\text { Cardiac Plasma...... } \\
\text { Pleural fluid... }\end{array}$ & $\begin{array}{l}5.2 \\
5.2\end{array}$ & $\begin{array}{l}4.0 \\
4.0\end{array}$ & $\begin{array}{l}2.8 \\
2.7\end{array}$ & $\begin{array}{l}0.9 \\
0.9\end{array}$ & $\begin{array}{l}2.0 \\
2.0\end{array}$ \\
\hline $\begin{array}{r}\text { Pneumonia Plasma..... } \\
\text { Pleural fluid . .... }\end{array}$ & $\begin{array}{l}5.2 \\
5.1\end{array}$ & $\begin{array}{l}4.1 \\
4.1\end{array}$ & $\begin{array}{l}2.7 \\
2.6\end{array}$ & $\begin{array}{l}0.9 \\
0.9\end{array}$ & $\begin{array}{l}2.0 \\
1.9\end{array}$ \\
\hline $\begin{array}{r}\text { Tuberculosis Plasma } . \\
\text { Ascites } \ldots \ldots \ldots\end{array}$ & $\begin{array}{l}5.1 \\
5.0\end{array}$ & $\begin{array}{l}3.8 \\
4.0\end{array}$ & $\begin{array}{l}2.7 \\
2.7\end{array}$ & $\begin{array}{l}0.9 \\
0.9\end{array}$ & $\begin{array}{l}1.9 \\
1.9\end{array}$ \\
\hline $\begin{array}{r}\text { Carcinoma Plasma.... } \\
\text { Ascites . . . . . . }\end{array}$ & $\begin{array}{l}5.0 \\
4.9\end{array}$ & $\begin{array}{l}3.7 \\
4.0\end{array}$ & $\begin{array}{l}2.7 \\
2.8\end{array}$ & $\begin{array}{l}0.9 \\
0.9\end{array}$ & $\begin{array}{l}2.0 \\
2.0\end{array}$ \\
\hline $\begin{array}{r}\text { Carcinoma Plasma..... } \\
\text { Ascites .......... }\end{array}$ & $\begin{array}{l}5.1 \\
5.1\end{array}$ & $\begin{array}{l}3.8 \\
3.9\end{array}$ & $\begin{array}{l}2.7 \\
2.7\end{array}$ & $\begin{array}{l}0.9 \\
0.9\end{array}$ & $\begin{array}{l}2.0 \\
2.0\end{array}$ \\
\hline
\end{tabular}

plasma. Figure 4 shows the relation between the percentage of albumin in the serous effusion and that in the plasma. As might be expected from the smaller size of the albumin molecule, the albumin apparently passes into the fluid more readily than does the globulin. Although the absolute amounts of albumin and globulin vary widely in both plasma and fluid, the proportion of albumin in the serous fluid is almost invariably higher than in the plasma when any single case is studied.

The proportion of $\beta$-globulin and fibrinogen in the fluid is generally lower than in plasma. The association of $\beta$-globulin with lipoids, often in particles of colloidal dimension, may explain its lowered proportion. The defibrinating action of the pleura, as pointed out by Denny and Minot (22), probably accounts for the relatively low amounts of fibrinogen found.

The total protein concentration of a serous effusion is generally characteristic of the underlying 


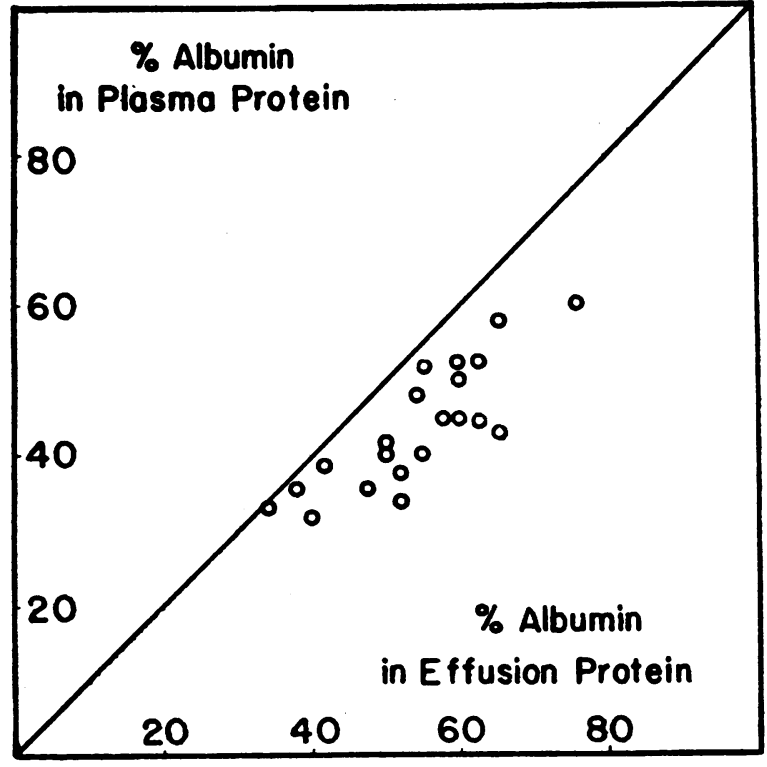

Fig. 4. The Relation Between the Proportions of

Albumin in Plasma and in Serous Efrusions

The proportion of albumin in the effusion fluid is higher than in plasma in all cases studied.

cause, but it seems impossible to draw a dividing line between different types on the basis of total protein content without encountering frequent exceptions. The ratio between the total protein concentration of the fluid and that of the plasma is more accurate, but some exceptions still occur. The reason for this difficulty is apparently that there is considerable overlapping of the causes of production.

The most dilute fluids are seen in the nephrotic syndrome, where hypoproteinemia allows the filtration of large amounts of fluid of low protein content $(16,17)$. Cirrhosis also produces fluids of very low protein content, with a combination of hypoproteinemia and increased venous pressure in the portal circulation. In cardiac fluids, the protein content is higher, with the appearance of anoxemia in addition to congestion $(18,19,20)$. In inflammatory fluids, severe local capillary damage gives rise to fluids approaching the composition of plasma. Because of the vast difference in size between even the largest plasma protein molecule and the erythrocyte, some of these fluids have almost the same protein composition as plasma, but contain comparatively few red blood cells.
The same three variables, colloid osmotic pressure, capillary pressure, and capillary damage, play a more or less important part in the production of all effusions. That we are dealing with a complex system is evidenced by the fact that attempts at analysis on one basis, e.g., the effects of hypoproteinemia or hypoalbuminemia on the protein content of cardiac effusions, lead to inconclusive results.

When cardiac effusions of high protein content are analyzed, it is evident that they differ from fluids of similar protein content produced by inflammatory changes. In Figure 5, the ordinate is a measure of the amount of protein in the fluid, while the abscissa is a measure of the differential filtration of albumin. It may be seen that cardiac effusions contain more albumin than inflammatory or neoplastic effusions of the same total protein content.

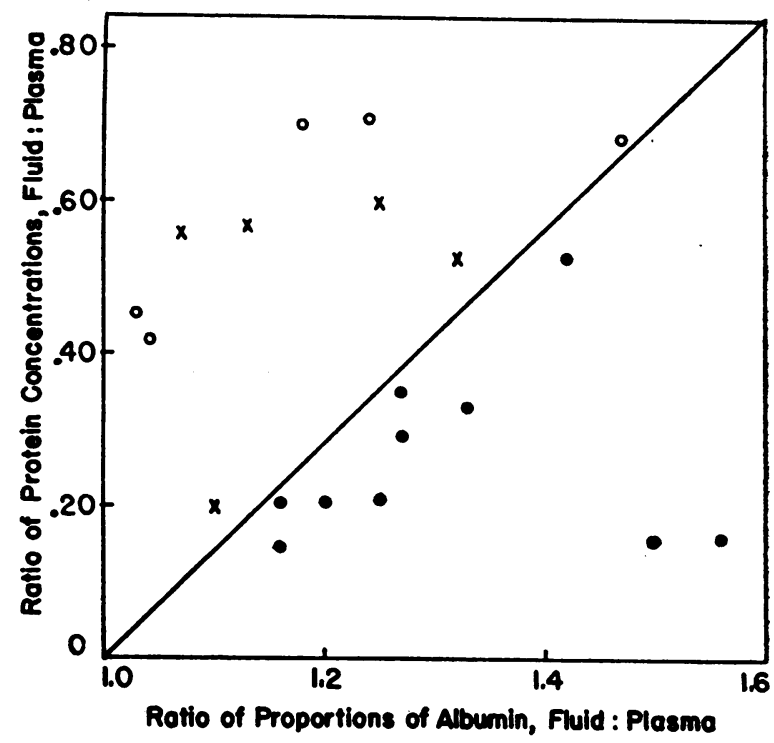

Fig. 5. Relative Filtration of Albumin in Various EFfusion Fluids

The ordinate is the ratio between the total protein concentrations of fluid and plasma. The abscissa is the ratio between the proportion of albumin in the fluid and that in the plasma, representing the differential filtration of albumin. It will be seen that the cardiac effusions show greater proportions of albumin than effusions of infectious or neoplastic origin with the same total protein content.

$$
\begin{aligned}
& O=\text { Cardiac } \\
& O=\text { Infectious } \\
& X=\text { Neoplastic }
\end{aligned}
$$


In serial taps from the same patient, the fluids tend to bear much the same relation to blood at each tap. We have seen no evidence for the theory of Desbordes (21) that albumin is converted into globulin in the serous cavities. An increase in the proportion of globulin on serial taps usually reflects a similar situation in blood.

\section{CONCLUSIONS}

1. The proteins of serous effusions show the same electrophoretic fractions as the plasma proteins.

2. The amounts of the various fractions in the fluid are determined by the composition of the plasma protein and by the factors producing the effusion.

3. Albumin is present in the same or higher proportion in the effusion, as compared with plasma, and $\beta$-globulin and fibrinogen in lower proportion.

4. Cardiac fluids show greater preferential filtration of albumin the greater the protein concentration. Infectious and neoplastic fluids show a similar but much less striking relation. On this basis a differentiation can apparently be made between effusions of the same total protein concentration.

5. There is no evidence of specific increase in any globulin fraction in an "exudate" beyond the proportion in blood.

\section{BIBLIOGRAPHY}

1. Loeb, R. F., Atchley, D. W., and Palmer, W. W., On the equilibrium condition between blood serum and serous cavity fluids. J. General Physiol., 1922, $4,591$.

2. Hastings, A. B., Salvesen, H. A., Sendroy, J., and Van Slyke, D. D., Studies of gas and electrolyte equilibria in the blood. IX. The distribution of electrolytes between transudates and serum. J. General Physiol., 1927, 8, 701.

3. Reuss, A., Das Verhältniss des specifischen Gewichts zum Eiweissgehalt in serösen Flüssigkeiten. Deutsch. Arch. f. Klin. Med., 1881, 28, 317.

4. Runeberg, J. W., Klinische Studien über Transsudationsprocesse im Organismus (2). Ueber den Gehalt an festen Bestandtheilen mit Abzug des Albumins und an Chloriden in pathologischen Transsudaten. Deutsch. Arch. f. Klin. Med., 1884, $35,266$.

5. Paddock, F. K., Jr. (To be published.)

6. Tiselius, A., A new apparatus for electrophoretic analysis of colloidal mixtures. Trans. Faraday Soc., 1937, 33, 524.

7. Tiselius, A., Electrophoresis of serum globulin. Biochem. J., 1937, 31, 313.

8. Stenhagen, E., Electrophoresis of human blood plasma; electrophoretic properties of fibrinogen. Biochem. J., 1938, 32, 714.

9. Svensson, H., Direkte photographische Aufnahme von Elektrophorese-Diagrammen. Kolloid Ztschr., 1939, 87, 181.

10. Longsworth, L. G., Shedlovsky, T., and MacInnes, D. A., Electrophoretic patterns of normal and pathological human blood serum and plasma. J. Exper. Med., 1939, 70, 399.

11. Luetscher, J. A., Jr., Electrophoretic analysis of plasma and urinary proteins. J. Clin. Invest., 1940, 19, 313.

12. Luetscher, J. A., Jr., Serum albumin. II. Identification of more than one albumin in horse and human serum by electrophoretic mobility in acid solution. J. Am. Chem. Soc., 1939, 61, 2888.

13. Longsworth, L. G., and MacInnes, D. A., An electrophoretic study of nephrotic sera and urine. J. Exper. Med., 1940, 71, 77.

14. Payne, S. A., and Peters, J. P., The plasma proteins in relation to blood hydration. VIII. Serum proteins in heart disease. J. Clin. Invest., 1932, 11, 103.

15. Blix, G., Quantitative Bestimmung von elektrophoretisch getrennten Serumglobulinen. Ztschr. f. d. ges. exper. Med., 1939, 105, 595.

16. Field, M. E., and Drinker, C. K., The rapidity of interchanges between the blood and lymph in the dog. Am. J. Physiol., 1931, 98, 378.

17. Weech, A. A., Goettsch, E., and Reeves, E. B., The flow and composition of lymph in relation to the formation of edema. J. Exper. Med., 1934, 60, 63.

18. Krogh, A., Landis, E. M., and Turner, A. H., The movement of fluid through the human capillary wall in relation to venous pressure and to the colloid osmotic pressure of the blood. J. Clin. Invest., 1932, 11, 63.

19. Landis, E. M., Jonas, L., Angevine, M., and Erb, W., The passage of fluid and protein through the human capillary wall during venous congestion. $J$. Clin. Invest., 1932, 11, 717.

20. Landis, E. M., Micro-injection studies of capillary permeability. III. The effect of lack of oxygen on the permeability of the capillary wall to fluid and to the plasma proteins. Am. J. Physiol., 1928, 83, 528.

21a. Desbordes, J., and Lévy, D., Sur le taux des protéines et l'équilibre sérine/globuline dans divers liquides d'épanchements. Compt. Rend. Soc. de Biol., 1938, 127, 494.

b. Desbordes, J., Notion d'éxsudat et de transsudat dans les liquides d'épanchement. Signification du rapport sérine/globuline. Compt. Rend. Soc. de Biol., 1938, 127, 784. 
22. Denny, G. P., and Minot, G. R., The coagulation of blood in the pleural cavity. Am. J. Physiol., 1916, 39, 455.

23. Philpot, J. St.L., Direct photography of ultracentrifuge sedimentation curves. Nature, 1938, 141, 283.

24. Myers, W. K., and Keefer, C. S., The relation of plasma proteins to ascites and edema in cirrhosis of the liver. Arch. Int. Med., 1935, 55, 349.
25. Foley, E. F., Keeton, R. W., Kendrick, A. B., and Darling, D., Alterations of serum protein as an index of hepatic failure. Arch. Int. Med., 1937, $60,64$.

26. Tumen, H., and Bockus, H. L., The clinical significance of serum proteins in hepatic diseases compared with other liver function tests. Am. J. M. Sc., 1937, $193,788$. 